\title{
APRESENTAÇÃO
}

\section{DOSSIÊ LAZER, EDUCAÇÃO E TECNOLOGIA}

Este dossiê é parte dos produtos finais do "V Colóquio Educação Física e Ciências Sociais em diálogo", evento realizado em parceria entre as instituições Universidade Metodista de Piracicaba (UNIMEP) e Universidade Federal de São Paulo (UNIFESP/Guarulhos), no mês de outubro de 2018. O evento teve como tema "Lazer, Educação e Tecnologia", tendo como aporte teórico um referencial voltado a gerar melhorias na Educação Básica brasileira, sobretudo ao que se refere aos processos de ensino e aprendizagem.

De acordo com informações do governo brasileiro (BRASIL, 2014), é nos anos finais do Fundamental que se encontra o maior problema de evasão escolar no Brasil. Nas aulas de Educação Física, os principais motivos geradores de exclusão e evasão das atividades propostas decorrem de questões de ordem didático metodológicas e de organização curricular.

Se os alunos não participam das aulas de Educação Física, eles deixam de ter acesso aos conhecimentos acerca do corpo e das práticas corporais (jogo, ginástica, luta, dança, esporte), assim como da educação para o lazer e perdem a possibilidade de refletir sobre as influências de seu meio social.

As práticas corporais, assim como os significados atribuídos ao corpo, são suscetíveis à dinâmica cultural de contextos específicos. Eles não escapam das lógicas de mercado, às quais servem de base para a sociedade capitalista e são transformadas em produtos a serem consumidos. Seja com finalidade estética, voltada à saúde, ou como forma de entretenimento, as práticas corporais, já há algum tempo, são mediadas pelos valores mercadológicos. Diante desse quadro é cada vez mais necessária a consideração da educação para o lazer em uma sociedade orientada pela cultura de consumo. Para que possa ocorrer um processo educativo que incentive a imaginação criadora, o espírito crítico, ou seja, uma educação para o lazer, não com o objetivo de criar necessidades, como assim o faz a mídia, mas satisfazer necessidades individuais e sociais entre elas educativas, as quais se transformam ao longo de toda o processo vital. Um dos canais para isso é a educação formal. Nesse sentido, a escola é um espaço fundamental para a realização de ações pedagógicas que se centrem na ressignificação do corpo e das práticas corporais, no sentido de uma educação para o lazer. 
$\mathrm{Na}$ atualidade, a virtualidade está presente em vários equipamentos que viabilizam a interação entre as pessoas e são apreciados por sujeitos de diferentes faixas etárias, tais como computadores e celulares. Assim, esses elementos podem ser agregados à aula, tornando-a mais interessante e dinâmica, de modo a incentivar a curiosidade dos alunos na busca por conhecimentos. Outro aspecto é a forma de uso da tecnologia pelos alunos na escola, como o uso de celulares que podem gerar problemas e dificuldades para o processo de ensino e aprendizagem se não houver uma finalidade pedagógica que inclua essa tecnologia no tempo de aula. Consideramos, portanto, que a discussão do tema desse dossiê é inovador e poderá trazer contribuições para o debate acadêmico no contexto brasileiro.

Os trabalhos que compõem o dossiê são: 1) Lazer e educação em parques urbanos: a comunicação visual no Parque Ibirapuera (Karine Regina Facini, Danilo dos Santos Lopes, Ricardo Ricci Uvinha). O trabalho se relaciona ao usufruto do turismo em parques urbanos apontando, entre as mais diversas possibilidades de abordagem, a comunicação visual como um dos elementos essenciais da hospitalidade; mais especificamente, analisa um dos pontos turísticos mais importantes da cidade de São Paulo como estudo de caso: o Parque Ibirapuera; 2) O tecnicismo/tarefismo nos cursos de formação profissional em Educação Física: algumas reflexões (Marcelo de Farias Teixeira). O autor realiza reflexões sobre o tecnicismo/tarefismo nos cursos de formação profissional em Educação Física. Como pano de fundo aborda a história da influência militar na área e um olhar crítico sobre ex atletas; 3) Cultura corporal de movimento e celular: implicações na participação dos alunos nas aulas (Jederson Garbin Tenório, Lucas de Andrade Carvalho). Os autores propõem reflexões sobre as implicações de hábitos relacionados as tecnologias, em especial, a utilização dos celulares, nas aulas de Educação Física e 4) A Educação Física na área da linguagem: o impacto da BNCC no currículo escolar (Barbara Cristina Aparecida dos Santos, Fabio Tomio Fuzii). Os autores discorrem sobre a Educação Física escolar do século XXI de modo a fazer aproximações com os estudos culturais e a própria área de Linguagem.

\section{REFERÊNCIA:}

BRASIL. 2014. Disponível em: $<\underline{\text { http://www.todospelaeducacao.org.br/reportagens- }}$ -tpe/32163/apenas-543-dos-jovens-concluem-o-ensino-medio-ate-os-19-anos/. Acesso em: 02 dez 2016.

\section{Cinthia Lopes da Silva}

Doutora em Educação Física pela Universidade Estadual de Campinas. Coordenadora do Grupo de Estudo e Pesquisa em Lazer, Práticas Corporais e Cultura. 